\title{
Contribution of the Immigrant Population to Demographic and Spatial Dynamics of the Basque Country
}

\author{
Juan Ramón Murua, Begoña Eguía \\ Department of Applied Economics V, University of the Basque Country (UPV/EHU), Bilbao, Spain \\ Email: juanramon.murua@ehu.es, bego.eguia@ehu.es
}

Received 22 April 2015; accepted 3 July 2015; published 6 July 2015

Copyright (C) 2015 by authors and Scientific Research Publishing Inc.

This work is licensed under the Creative Commons Attribution-NonCommercial International License (CC BY-NC).

http://creativecommons.org/licenses/by-nc/4.0/

(c) () (9) Open Access

\section{Abstract}

The twenty-first century begins with a rupture of the migratory pattern in the Basque Country, a region located in the north of Spain, transforming it from a community which exports its population to one which receives it. Despite the current economic crisis, the Basque Country continues to be a destination for foreigners, now in many cases coming from other Spanish regions most affected by this crisis. Given the quantitative and qualitative importance of these migration flows, in this research we analyze the contribution of immigrants to the demographic dynamics of the Basque Country. By also identifying their patterns of spatial localization, we examine their contribution to the correction or accentuation of regional imbalances in the population distribution. The results reveal that the demographic recovery rests primarily on contributions of this immigrant population, a population which also promotes the rejuvenation of an aging society, although it is far from correcting regional imbalances and may contribute to accentuating them.

\section{Keywords}

Immigration, Aging, Spatial Demography

\section{Introduction}

The Spanish population has grown continuously since the beginning of the twenty-first century, from 40.5 million inhabitants in 2000 to 47.2 million in 2012, a growth of $16.7 \%$ in that period. In 2012, a slight decline in population began, but there were still 46.7 million inhabitants in 2014. A large part of this growth can be explained by the net inflow of individuals from other countries: in just 12 years, it has grown from 1 million to 
over 5 million.

Spain had gone from being one of the European Union countries with the lowest percentage of foreign population (2.28\% of the total population in 2000), to almost the highest ranking in this indicator (only Germany surpasses Spain in the volume of immigrants) ${ }^{1}$. Despite the slowdown of new immigrants due to the economic crisis, immigrant population still exceeded $10.7 \%$ of the total population in 2014 (5.02 million).

In regards to the destination of foreigners, Catalonia, Madrid, the Valencian Community and Andalusia are the regions with the highest concentration. These happen to be the most populated regions of Spain, regardless of other aspects related to their structure and economic activities. By contrast, in the northwestern and western areas of the peninsula the immigrant population is noticeably lower.

The Basque Country, located in the Cantabrian area of northern Spain, has also been a participant in this influx of foreign population, although later and with less intensity than in other regions. At the end of the last century, foreigners represented less than $1 \%$ of the population of the Basque Country (0.7\% in 1998), but in 2014, a little over a decade later, they accounted for $6.5 \%$.

Being a recipient of this important contingent of the population can have implications at various levels: demographic, spatial, social, economic, etc. It can contribute to the growth of the population as a whole, altering not only the size of the total population but also its age structure, as the immigrants are relatively young. In addition, depending on their settlement patterns, it may influence the spatial distribution of the population.

The Basque Country, a region where the aging of its population exceeds the national average, enjoys a more favorable economic situation, even during the stage of economic crisis, making it somewhat "special." It is an attractive option for foreigners already settled in other regions of Spain. Given the profile of these new members of the population, their influx can be considered a way to cushion not only the demographic loss but also the aging Basque population - an aging that will be accentuated in the absence of prompt corrective measures. In fact, the latest population projections of the Basque Statistics Institute (Eustat) estimate that $26.5 \%$ of the population will be over age 65 by 2026, with a life expectancy for men of 82.6 years and 88.4 for women.

The objective of this research is to identify the patterns of spatial localization of this immigrant population in the Basque Country and its contribution to the correction (or accentuation) of the spatial imbalances in the distribution of the population. It also seeks to analyze the actual role the immigrant population plays or could play in the recovery and rejuvenation of the Basque population.

The analysis is based primarily on sources of statistics from the National Institute of Statistics (INE). The Municipal Population Register (Statistics of the Continuous Municipal Register, with reference to the 1st of January of each year) provides population data on natives and immigrants. The Statistics of Migration facilitate data annually on movements of population and migratory balances (external and internal).

The work is structured as follows: Section 2 reviews some studies that include the main perspectives from analysis of the phenomenon of immigration. Sections 3 and 4 focus on the study of immigration in the Basque Country: its contribution to the recovery of the population, its age structure and its spatial distribution. Finally in Section 5, we present the main conclusions and suggestions arising from the research.

\section{The Phenomenon of Immigration: Previous Studies}

Various theories attempt to explain the migration phenomenon from different perspectives, e.g., economic, labor market, social networks, etc. [1]. The differences in opportunities or net economic benefits (mainly wage differences or existence of employment opportunities, irrespective of any other factors) are the main cause of migration [2]. The persistently large difference in opportunities is a powerful call for migratory movements, be they regional or international.

Migrations are inherently spatial phenomena, though the consequences of population movements go beyond mere changes and displacements of human resources. The study of migration is above all the study of the behavior of individuals and groups and their integration into the economies of recipient countries, which makes it a complex issue about which perspective can be gained from interdisciplinary analysis ([3]-[10]).

Given its complexity, the specialized literature approaches immigration from different angles. Some authors study the determinants of these migration flows ([11] for OECD countries; [12] for Canada and the USA; [13] for countries of the European Union; or [14] for Spain). There is also ample literature that addresses the effects of the arrival of new immigrants. Reference [15] focuses on the economy in the USA, [16] in the UK and [17] in

\footnotetext{
${ }^{1}$ In the article, we use the terms foreigner and immigrant interchangeably to refer to those who reside in Spanish territory but do not have Spanish nationality.
} 
Ireland, Spain and Greece. Focusing on the Spanish case, [18] notes that immigration has had a positive impact on business and, in addition to the effects on the labor market and on economic growth, the arrival of immigrants has also had an impact on the social welfare system. Reference [19] discusses the same aspects in the Basque Country. Reference [20] focuses on the impact immigration has on the viability and sustainability of the public pension system. The impact of immigration on the labor market is also the focus of numerous studies: [21] or the successive reports prepared for the Permanent Observatory of Immigration under the Ministry of Labor and Immigration ([22] [23]).

We can also find a vast amount of national and international literature related to the location and geographic distribution of these new members of the population. Given that, as noted above, the migrations are also phenomena of space, the study of their possible influence on spatial distribution is of interest, an aspect barely studied and which is addressed in this research. In various countries foreign immigration is considered an alternative to alleviate the problem of rural depopulation, while helping the economic revitalization of those areas ([24] or [25]). In relation to the location and geographical distribution of the immigrant population, [26] perceive remarkable spatial differences in the city of Barcelona and its metropolitan region. Reference [27] considers the foreign population to be the main factor of population growth in most of the rural municipalities in Spain. Also [9] highlight the fundamental role of immigration as slowing the depopulation in rural Spain, and add that even during the period of crisis, migration flows to rural areas manage to compensate for the losses of the native population, albeit to a lesser degree.

A steady exodus of the population is incompatible with any aspiration for endogenous development [28]. The mass emigration of some areas limits their capacity for growth, due to weakening their production and their human and social capital and, in addition, their capacity for economic development [29]. The arrival of immigrants could be seen as a solution to the depopulation of some municipalities. However, there could be some doubt or skepticism about the viability of relying solely on the immigrant population to compensate for problems of depopulation and aging in some areas.

In some countries (USA, Canada or Australia, mainly) studies about patterns of spatial distribution and mobility of the immigrant population are common. These countries have specific programs aimed at directing the immigrant population to less populated areas and/or areas with labor shortages [30]. In Spain, however, the spatial perspective of the research related to immigration is quite recent and therefore existing literature with that approach is limited. One aim of this work is to help to fill this gap.

\section{Immigration in the Basque Country, 2000-2014}

The Basque Country, located in the Cantabrian zone of northern Spain, is a region that deserves special examination. Its population experienced a slight decline in the last quarter of the century. The population levels it had at the beginning of the 1980s were not reached again until the early part of the 21st century, almost 30 years later. A recovery began at the turn of the millennium and continues to the present, with a growth of $4.3 \%$ in the period of 2000-2014.

Due to the significant inflow of immigrants from various countries, as well as from other regions of Spain, the last decade has been witness to a series of fundamental changes in the size and composition of the population.

The twenty-first century begins with a rupture in the migratory patterns of the Basque Country, which ceases to be a region that exports its population and becomes instead a host region. The relative weight of foreign residents has increased considerably (from 21,140 registered in 2000 to 141,316 in 2014), which implies a shift of $1.0 \%$ to $6.5 \%$ of the total population (see Figure 1 ). The presence of immigrant population in the Basque Country is relatively less than in Spain as a whole, and also a bit delayed. However, its contribution has been crucial for the maintenance and growth of the Basque population.

In addition, it is the region (or autonomous community, as it is referred to in Spain) with the highest inter-regional migration balance of foreign population during the years 2008-2013 (and, although the data are provisional, also in 2014). That is to say, it has the greatest net inflow of immigrant population coming from the rest of Spanish autonomous communities (Figure 2).

Some studies indicate that in Spain, the immigrant population extends from the south and the Mediterranean coast towards the interior and the center of the peninsula [31], while Madrid is one of the main gateways into the country.

Other authors [32] demonstrate that the longer the time of residence in the country, the greater the propensity for internal migration, which suggests the importance of knowledge of the host country's labor market. Those 


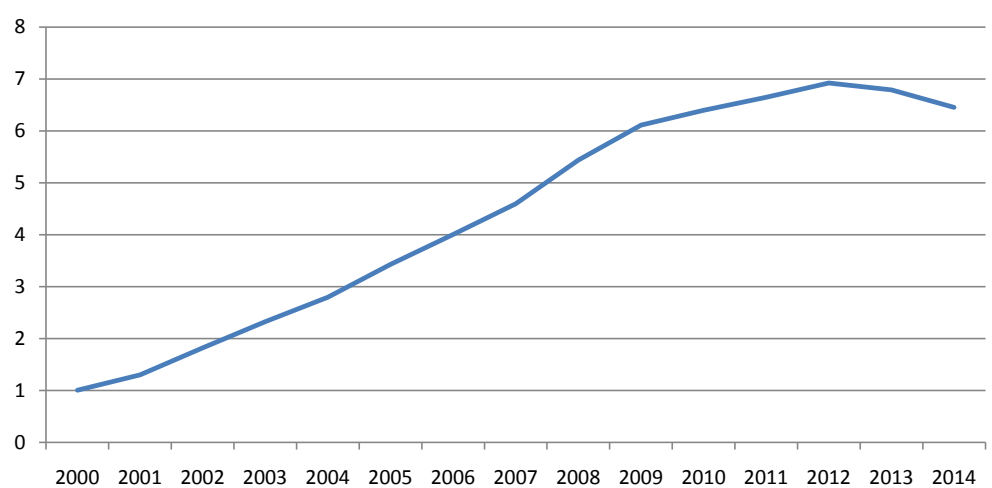

Figure 1. Percentage of immigrants in the Basque Country. Source: Municipal Register of the INE.
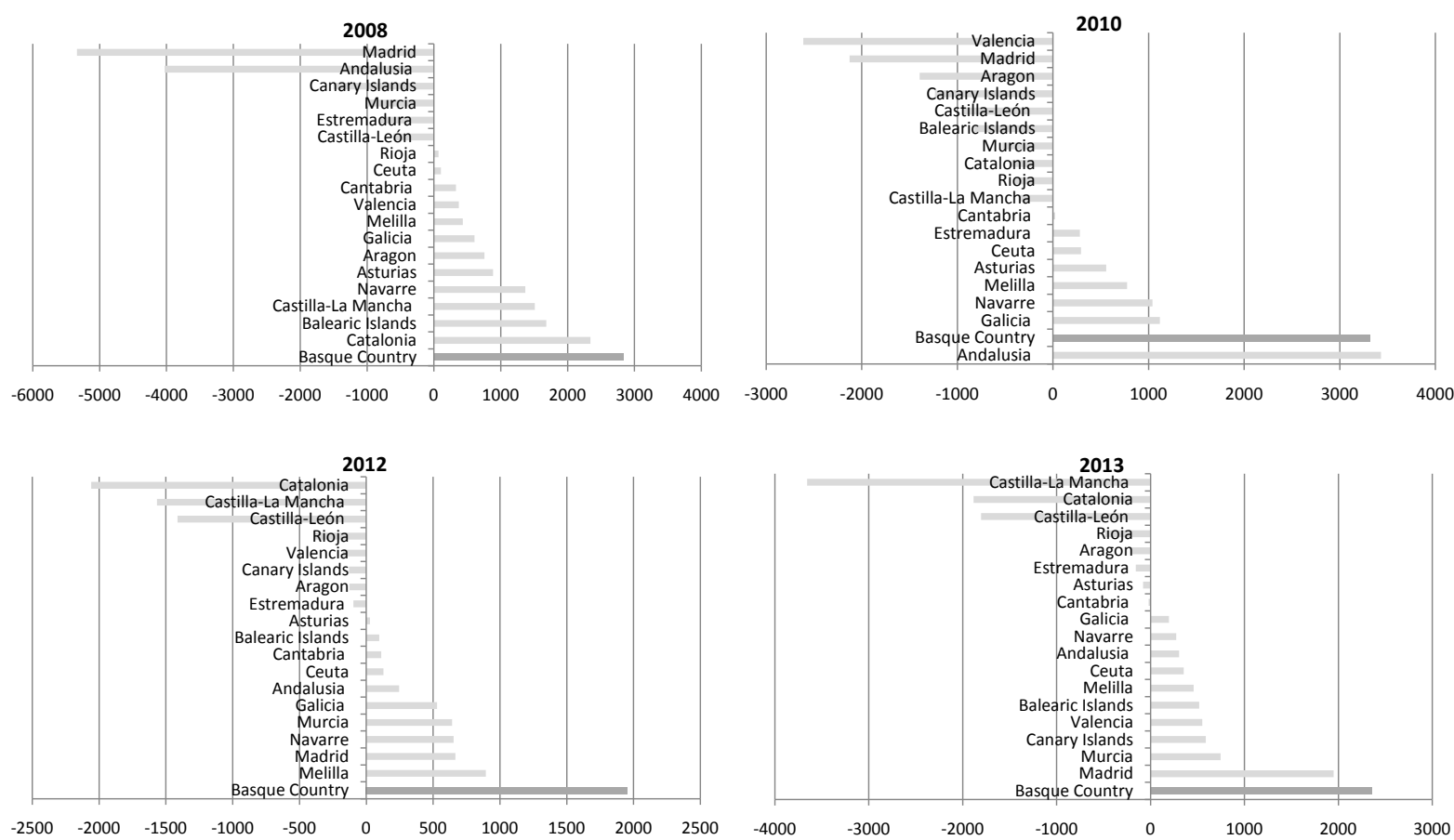

Figure 2. Inter-regional migratory balance of foreign population in the Basque Country. 2008-2013. Source: Statistics of Migrations, INE.

communities initially receiving the majority of immigrant population later become the main source of domestic migration towards regions where the impact of the economic crisis is less severe.

Reference [9] points out, in this respect, that the comparison of the spatial distribution maps of the immigrant population during different periods in Spain shows that the populations tends to spread gradually towards the interior of the peninsula and push out into the north from the Ebro Valley. Further to the north and northwest (Cantabrian coast) the presence is smaller but varied, perhaps due to the scattered nature of the habitat and to the climatology, as well as the fact that productive activities (mainly intensive agriculture, construction and tourism) that traditionally have demanded this type of workforce represent a lighter portion of the economy of that region.

In this regard, the recent major influx of immigrants to the Basque Country is understandable because it is among the economically best-performing regions: the GDP per capita is higher and the unemployment rate lower than in most other Spanish regions. In addition, given current trends, it is foreseeable that this inter-regional flow of immigrants to the Basque Country will continue. 
The favorable economic situation during that period also caused the local workforce to discard certain kinds of jobs that went on to be covered by the immigrant workforce. It also favored a higher level of integration of native women in the labor market, consequently creating a new demand for labor in domestic work, child care and care for the elderly.

The start of the crisis marked a decline in the net inflow of population from other countries. However, it was a pulling force on foreign populations living in the most disadvantaged regions of Spain.

Although the economic crisis has been present in all areas of Spain, it has not affected all territories alike. Reference [33] concludes that eight of the ten least vulnerable Spanish cities, and therefore more resistant to the crisis, are Basque. They argue that a lower exposure to the real estate sector, the internationalization of some of its industry, active policies in R\&D, and social protection, are factors that may account for the positive performance of Basque municipalities. Regardless of other aspects, such as the existence of immigrant networks, this better performance seems to have been an attracting factor for foreign populations located initially throughout the Spanish territory.

\section{Results}

\subsection{Contribution of Immigrant Population to the Growth}

In addition, the contribution of this new population has been vital to the growth of the Basque population. The calculation of that contribution comes from the following method: total population pobT is the aggregate of the population with Spanish nationality $p o b N$ and the population with foreign nationality pobX. Consider any two periods, $t$ and $s$, then you can write

$$
\frac{p o b T_{t}-p o b T_{s}}{p o b T_{s}}=\left(\frac{p o b N_{t}-p o b N_{s}}{p o b N_{s}} \times \frac{p o b N_{s}}{p o b T_{s}}\right)+\left(\frac{p o b X_{t}-p o b X_{s}}{p o b X_{s}} \times \frac{p o b X_{s}}{p o b T_{s}}\right)
$$

to obtain the growth of the total population as the weighted sum of the growth of the national population and the immigrant population in a given period $(t-s)$. We examine the period of 2000-2014 because migration flows begin to exhibit significant figures at the beginning of the century. The results are shown in Table 1.

Considering the population of the region as a whole, which increased by 4.3\% between 2000 and 2014, the contribution of the foreign population to growth has been decisive, given that the contribution of the national population has been negative. In other words, without the contributions of the immigrant population, the Basque Country would have lost population.

\subsection{Age Structure of the Immigrant Population}

Upon analyzing the age structure of the population, we find that the foreign age structure has little resemblance to that of the national.

In the native group we observe an aging population with high life expectancy and a reduced child population. More than $21 \%$ of the native population is over the legal age of retirement (mostly women, at $57.8 \%$ ) and only about $13 \%$ are under 14 years of age.

Upon comparing the population pyramids of 1971 and 2014 (see Figure 3), we appreciate the process of an aging population in the Basque Country. While the decline in birth rate has made the base of the pyramid thinner over time, the increase in life expectancy has increased the volume of population of elderly people.

The Basque Country is immersed in a process of aging, more pronounced than that of Spain as a whole. The proportion of people over 64 years of age has grown steadily, reaching over $20 \%$ of the resident population on January 1, 2014, a percentage that is higher than the Spanish average of $18 \%$ (Figure 4).

Dependency rates (ratio of the population under the age of 16 and older than 64, to the population of 16 to 64 years old, expressed as a percentage) also reveal an aging of the resident population in the Basque Country, once again higher than that of Spain as a whole (see Figure 5).

This indicator has clear economic significance as it represents the ratio of the potentially inactive population to the potentially active one, a ratio which also shows continued growth.

Focusing, however, on the foreign population, we see that elderly immigrants represent a very small percentage (2.36\% are over age 65) and the vast majority (41.31\%) are between 25 and 39 years of age, of which $46.47 \%$ are male, which corresponds to the entry age of the immigrant in Spain. Only $18.57 \%$ of foreigners residing in 


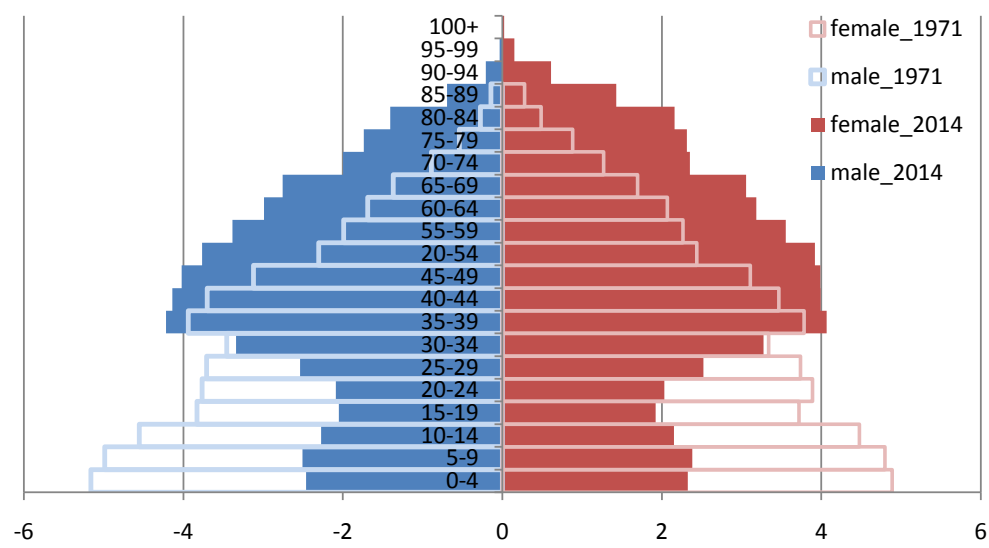

Figure 3. Population Pyramid Source: our own design, based on data from the Municipal Register (INE).

Proporción de personas mayores de 64 años

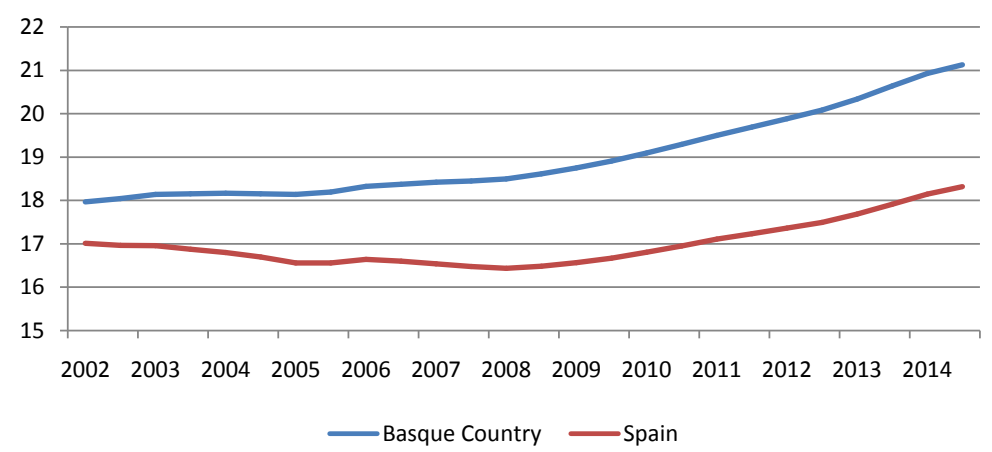

Figure 4. Percentage of population over 64 years of age. Source: Municipal Register (INE).

Tasa de dependencia

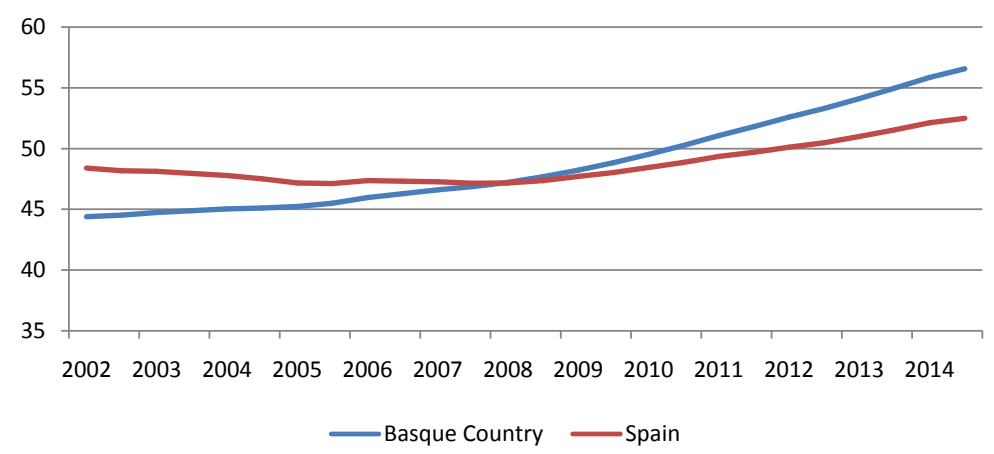

Figure 5. Age dependency ratio. Source: Municipal Register (INE).

the Basque Country are older than 45 (Figure 6).

This different age structure, with hardly any individuals of advanced age, may constitute a certain slow down of the progressive aging of the Basque population and a means of rejuvenation of the total population, since these new groups also have higher birth rates (Figure 7).

In addition to the strictly quantitative aspects, one of the effects most relevant to the influx of immigrant population is occurring in the age structure of the population, which will have implications on the labor market, as well as on the demography and the economy as a whole, given that the majority of the immigrant population is 
Table 1. Total population growth, 2000-2014. Contribution of national and immigrant population to the growth (\%).

\begin{tabular}{ccccc}
\hline & Growth of Total Pop. & $\begin{array}{c}\text { Contribution of National } \\
\text { Pop. }\end{array}$ & $\begin{array}{c}\text { Contribution of } \\
\text { Immigrant Pop. }\end{array}$ & $\begin{array}{c}\text { Contribution Immigrant } \\
\text { Pop./Growth of Total Pop. }\end{array}$ \\
\hline Alava & 12.37 & 4.38 & 7.98 & 64.55 \\
Guipuzcoa & 5.27 & -0.41 & 5.68 & 107.78 \\
Biscay & 1.69 & -3.49 & 5.19 & 306.32 \\
Basque Country & 4.31 & -1.42 & 5.73 & 132.95 \\
\hline
\end{tabular}

Source: Our own design, based on data from the Municipal Register (INE).

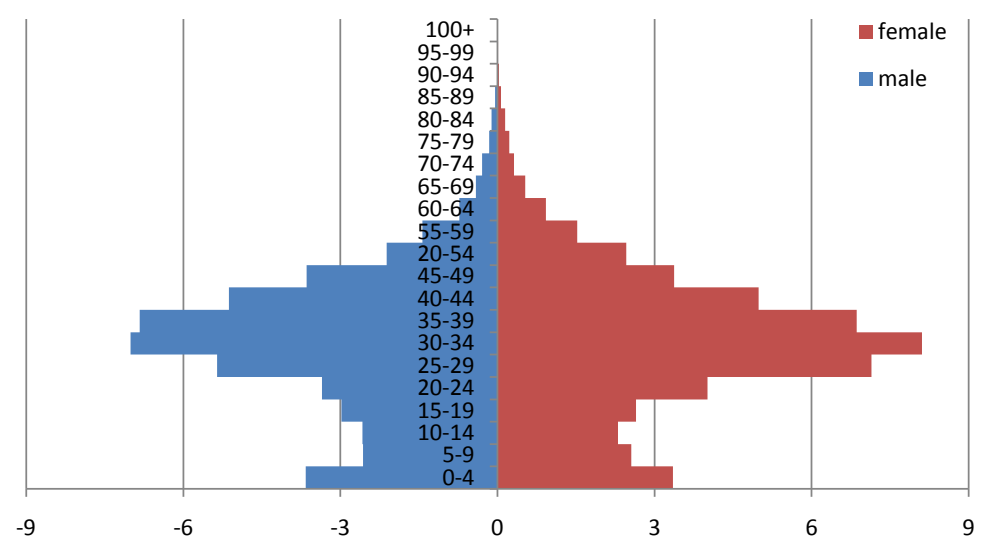

Figure 6. Immigrant population pyramid, 2014. Source: Municipal Register of (INE).

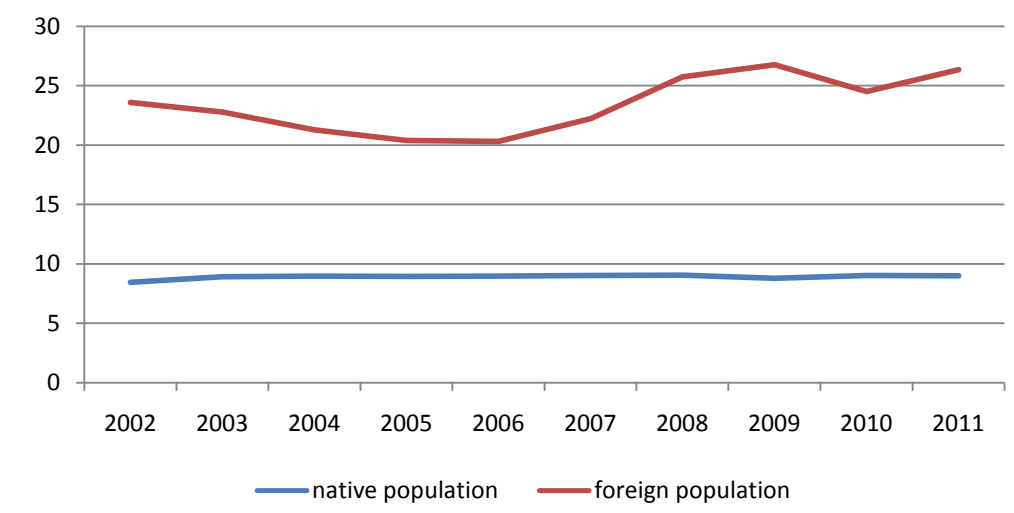

Figure 7. Birth rates. Native and foreign population Source: Natural Movement of Population (INE).

of working age and contributes significantly to raise the rate of activity.

It should be emphasized that this influx of foreign population has occurred spontaneously, that is to say it has not been the result of any previously planned programs or special measures. This suggests that if we were to design programs that provided a means for planning and popularization, we could achieve higher levels of attraction of immigrants.

It is therefore of interest to arbitrate planning policies and management of the flow of immigration in order to guide immigrants, according to the objectives of population policy, towards those areas with the greatest need for new population, to act as a labor resource that can meet the potential demand for certain types of occupations.

Also, depending on their patterns of spatial localization, immigrants may influence the distribution of the 
population in the region, an aspect also of great importance insofar as it could contribute to either accentuating or mitigating the imbalances in the regional distribution of the population.

\subsection{Spatial Distribution of the Immigrant Population}

In the Basque Country, three major urban areas have been established, the center of each being the provincial capitals, which are gradually expanding towards municipalities and well-connected neighboring districts. These three metropolitan areas consolidate about $75 \%$ of the population of the Basque Country into an area equal to one fourth of the region. This has resulted in a very uneven spatial distribution of population and economic activity, with significant harm primarily to rural areas. It is a phenomenon present in many regions of industrialized countries and the European Union in particular, which is why policies to promote the development of rural areas have been implemented for more than the last two decades [34].

Given the existing imbalances in the regional distribution of the population of the Basque Country, it is interesting to analyze the patterns of regional settlement of the immigrant population, especially considering the role it has played in slowing down depopulation of some rural areas of Spain [9].

We observe that, in general, the distribution of the immigrant population in Spain follows a similar pattern to that of the native population. As in most countries, it initially tends to be concentrated in large urban areas which are more attractive in terms of employment opportunities and provision of services [35]. As noted by [2], the individual not only considers the relative income but also the services and advantages offered by different regions.

In regards to total population, the strongest demographic concentrations are in the provinces of Alava and Biscay, whose metropolitan areas concentrate nearly $80 \%$ of the provincial population in about a quarter of the territory. In the province of Guipuzcoa, the imbalance is less pronounced, since the metropolitan area formed around the capital concentrates only $62.5 \%$ of the population.

This concentration is even higher if we refer to the immigrant population, and especially to the one living in the province of Alava, where nearly $90 \%$ of immigrants are concentrated in the capital and its periphery. At a general level, the provincial distribution of the immigrant population roughly corresponds to the weight of population of each of the provinces.

The Gini coefficients allow for the comparison of the degree of concentration of foreign and national populations in the Basque municipalities (Table 2) ${ }^{2}$.

Alava is the province with the largest imbalances in the spatial distribution of the population. The Gini coefficient, as an expression of the degree of inequality, has the highest values in that province, both in the native and immigrant population (although the values of the latter are somewhat larger), indicating a greater degree of concentration.

Imbalances in Biscay and Guipuzcoa are less pronounced, but are far from uniformity: Gini coefficients in 2014 are 0.79 and 0.73 , respectively, for the nationals and 0.84 and 0.76 , respectively, for the immigrants. In Biscay, $29.6 \%$ of the indigenous population is concentrated in the capital, and $38.8 \%$ of the foreign population of the province. In the case of Guipuzcoa, these percentages are $26 \%$ and $27 \%$, respectively.

In general we observe that the immigrant population presents higher levels of concentration than the national population; however, with the passage of time, the degree of concentration decreases. The resulting coefficients

Table 2. Gini coefficients. National and immigrant population. 2000, 2008, 2014.

\begin{tabular}{|c|c|c|c|c|c|c|}
\hline & \multicolumn{2}{|c|}{2000} & \multicolumn{2}{|c|}{2008} & \multicolumn{2}{|c|}{2014} \\
\hline & National & Immigrant & National & Immigrant & National & Immigrant \\
\hline Alava & 0.8852 & 0.9209 & 0.8767 & 0.9170 & 0.8787 & 0.9112 \\
\hline Guipuzcoa & 0.7444 & 0.7864 & 0.7352 & 0.7751 & 0.7319 & 0.7588 \\
\hline Biscay & 0.8099 & 0.8730 & 0.7971 & 0.8453 & 0.7910 & 0.8392 \\
\hline Basque Country & 0.8148 & 0.8632 & 0.8035 & 0.8484 & 0.7998 & 0.8385 \\
\hline
\end{tabular}

Source: our own design, based on data from the Municipal Register (INE)

${ }^{2}$ This coefficient is a measure of inequality with values between 0 and 1 , where 0 corresponds to perfect uniformity (uniform distribution of the population in the territory) and 1 to perfect inequality. In other words, proximity of the indicator to the unit indicates a total absence of uniformity in the distribution of the population. 
for recent years, compared with 2000, have slightly lower values.

As the immigrant population's time of residence increases, they become familiar with resources (strengthening their social capital) and adjust to new environments and activities and, as a result, tend to spread out geographically, decreasing the concentration in some areas and lessening the value of the coefficients. In this regard, although initially the opposite happens, immigrants' stabilization in the Basque Country could be considered a way to help smooth out the current imbalances in the distribution of the population throughout the region.

\section{Concluding Remarks}

Despite the crisis, the Basque Country continues to be a target of foreign population, partially because during the last few years foreign immigration coming from other Spanish regions harder hit by the economic crisis has increased significantly, a tendency which continues although to a lesser degree. The Basque Country is the region with the lowest rate of unemployment (16.6\% in the last quarter of 2014, compared with the national average of 23.7\%) and is among those with the highest GDP per capita. Testament to the favorable social and economic situation is that eight of the ten Spanish cities considered least vulnerable or most resistant to the crisis are found in this region.

The contribution of this immigrant population had been crucial to achieving a demographic recovery in the Basque Country, which grew by 4.3\% between 2000 and 2014, since the contribution of the local population had been negative. Without the contributions of the foreign population, the Basque Country would have lost population.

The influx of immigrant population, predominantly young and with high birth rates constitutes a kind of slowing of the progressive aging of the Basque population and a means of rejuvenation of the total population.

Implications are not only demographic, but also economic. The immigrant population, given that it is primarily in its working years, contributes significantly to raise the rate of economic activity, therefore affecting both the labor market and economic activity.

With regard to the location and spatial distribution of the immigrant population, in general we observe that their behavior is not very different from that of the nationals: their main destinations are the metropolitan areas (provincial capitals and neighboring municipalities), areas that have gained notable economic momentum over the past decade and that, therefore, offer more employment opportunities than other areas.

The immigrant population, in the absence of other channels of information, and considering the type of jobs they mainly occupy, find better employment opportunities in the major urban areas which are where they tend to initially set up residence.

In this regard, the degree of concentration of the immigrant population is higher than that of the national population, indeed the indices of concentration are also higher. Nevertheless, it has been observed that with the passage of time, these indices of concentration tend to fall, which indicates that the immigrant population gradually tends to spread out geographically, settling even into rural areas with severe depopulation and aging problems. Although immigrants' settlement patterns initially contribute to accentuating regional imbalances, that effect tends to correct itself the longer the immigrant remains in the country.

Moreover, these additions to the population are particularly significant if we consider that they have occurred without prior planning, which suggests that with a minimum level of planning and specific programs, we could easily draw higher levels of immigrant populations, a portion of which could be directed to the most demographically disadvantaged regions.

The interest of arbitrating this type of policy planning and management is more evident if one considers the latest demographic projections of the Basque Statistics Institute (Eustat), according to which, by the year 2026, the Basque Country will have 100,000 fewer people, in addition to a $26.5 \%$ of its population over 65 years of age.

Considering the foreseeable decline in population, it is entirely justified that policies related to planning and management of migration receive greater attention and have a greater role, as they may be one of the few feasible means to the revitalization of the population.

Local institutions, due to their proximity and to their knowledge of the environment and its social framework, should play a more active role in the management of some of these active policies aimed at the immigrant population. 


\section{Acknowledgements}

The authors gratefully acknowledge the financial assistance received from the University of the Basque Country/Euskal Herriko Unibertsitatea, UPV/EHU (research project EHU14/46) and the valuable comments provided by anonymous reviewers.

\section{References}

[1] OECD (2009) The Future of International Migration to OECD Countries. http://www10.iadb.org/intal/intalcdi/PE/2009/03706.pdf

[2] Borjas, G.J. (2000) Economics of Migration. International Encyclopedia of the Social and Behavioral Sciences, Section No. 3.4, Article No. 38.

[3] Recolons, L. (2005) Las Migraciones Exteriores en la Evolución de la Población de España, 1950-2004. Migraciones, 17, 45-89.

[4] Torres, R. (2007) Las Migraciones Internas en el País Vasco durante el periodo 1991-2001. Evidencias de un Proceso de Contraurbanización. Boletín de la Asociación de Geógrafos Españoles, 43, 85-106.

[5] Ikuspegi (2008) Población Extranjera en la CAPV 2008. Panorámica de la Inmigración, No. 23. Observatorio Vasco de Inmigración.

[6] Irastorza, N. (2008) Entrepreneurial Activity of Immigrants in Spain. Ph.D. Thesis TDIVC.001. Basque Institute of Competitivenes, Deusto Foundation, Orkestra.

[7] Moreno, G. and Aierdi, X. (2010) Anuario de la Inmigración en el País Vasco 2010. Ikuspegi@k, Observatorio de Asuntos Sociales.

[8] Aja, E., Arango, J. and Alonso, J.O. (2010) Inmigración y Crisis Económica: Impactos Actuales y Perspectivas de Futuro. Anuario de la Inmigración en España, Edición 2010. Edicions Bellaterra, S.L.

[9] Collantes, F., Pinilla, V., Sáez, L.A. and Silvestre, J. (2013) Reducing Depopulation in Rural Spain: The Impact of Immigration. Population, Space and Place, 20, 606-621. http://dx.doi.org/10.1002/psp.1797

[10] Bodvarsson, O.B. and Van den Berg, H. (2013) The Economics of Immigration. Editorial Springer, New York. http://dx.doi.org/10.1007/978-1-4614-2116-0

[11] Lewer, J.J. and Van den Berg, H. (2008) A Gravity Model of Immigration. Economics Letters, 99, 164-167. http://dx.doi.org/10.1016/j.econlet.2007.06.019

[12] Karemera, D., Iwuagwu, V. and Davis, B. (2000) A Gravity Model Analysis of International Migration to North America. Applied Economics, 32, 1745-1755. http://dx.doi.org/10.1080/000368400421093

[13] Ramos, R. and Suriñach, J. (2013) A Gravity Model of Migration between ENC and EU. Research Institute of Applied Economics Working Paper 2013/17, Regional Quantitative.

[14] Cebrián, M. (2009) Los Determinantes de los Flujos Migratorios Internacionales: El Caso Español, $1995-2007$. Principios: Estudios de Economía Política, 14, 49-70.

[15] Peri, G. and Sparber, C. (2009) Task Specialization, Immigration and Wages. American Economic Journal: Applied Economics, 1, 135-169. http://dx.doi.org/10.1257/app.1.3.135

[16] Levie, J. (2007) Immigration, In-Migration, Ethnicity and Entrepreneurship in the United Kingdom. Small Business Economics, 28, 143-169. http://dx.doi.org/10.1007/s11187-006-9013-2

[17] Muñoz de Bustillo, R. and Antón, J.I. (2010) From Sending to Host Societies: Immigration in Greece, Ireland and Spain in the 21st Century. Industrial Relations Journal, 41, 563-583. http://dx.doi.org/10.1111/j.1468-2338.2010.00586.x

[18] Fundación Ideas (2011) La Contribución de la Inmigración a la Economía Española. Evidencias y Perspectivas de Futuro, Madrid.

[19] Arriola, J., Gómez, C. and Andrés, X. (2008) El Impacto Económico de la Inmigración Extracomunitaria en la Comunidad Autónoma del País Vasco. Departamento de Vivienda y Asuntos Sociales del Gobierno Vasco.

[20] Serrano, F., Eguía, B. and Ferreiro, J. (2011) Public Pensions’ Sustainability and Population Ageing: Is Immigration the Solution? International Labour Review, 150, 63-79. http://dx.doi.org/10.1111/j.1564-913X.2011.00105.x

[21] Cuadrado, J.R., Iglesias, C. and Llorente, R. (2007) Inmigración y Mercado de Trabajo en España (1997-2005). Informes de Economía y Sociedad de la Fundación BBVA.

[22] Pajares, M. (2010) Inmigración y Mercado de Trabajo. Informe 2010. Observatorio Permanente de la Inmigración. Ministerio de Trabajo e Inmigración. 
[23] Carrasco, C. and García, C. (2011) Inmigración y Mercado de Trabajo. Informe 2011. Observatorio Permanente de la Inmigración. Ministerio de Trabajo e Inmigración.

[24] Dahlsten, S. (2004) Key Policy Coherence Issues in Agriculture and Migration. Institutional Approaches to Policy Coherence for Development OECD Policy Workshop. http://www.oecd.org/dataoecd/24/26/31744363.pdf

[25] Stockdale, A. (2006) Migration: Prerequisite for Rural Economic Regeneration? Journal of Rural Studies, 22, $354-366$. http://dx.doi.org/10.1016/j.jrurstud.2005.11.001

[26] Bayona, J. and Gil, F. (2008) El Papel de la Inmigración Extranjera en la Expansión de las Áreas Urbanas. El Caso de Barcelona (1998-2007). Scripta Nova, Revista Electrónica de Geografía y Ciencias Sociales, 12, 161.

[27] Roquer, S. and Blay, J. (2008) Del Éxodo Rural a la Inmigración Extranjera: El Papel de la Población Extranjera en la Recuperación Demográfica de las Zonas Rurales Españolas (1996-2006). Scripta Nova, Revista Electrónica de Geografía y Ciencias Sociales, 12, 129.

[28] Muilu, T. and Rusanen, J. (2003) Rural Young People in Regional Development, the Case of Finland in 1970-2000. Journal of Rural Studies, 19, 295-307. http://dx.doi.org/10.1016/S0743-0167(03)00003-2

[29] Stockdale, A., Findlay, A. and Short, D. (2000) The Repopulation of Rural Scotland: Opportunity and Threat. Journal of Rural Studies, 16, 243-257. http://dx.doi.org/10.1016/S0743-0167(99)00045-5

[30] OECD (2003) Trends in International Migration 2003. http://www.oecd.org/els/mig/trendsininternationalmigration2003.htm

[31] Camarero, L., Cruz, F., González, M., Pino, J., Oliva, J. and Sampedro, R. (2009) La Población Rural de España. De los Desequilibrios a la Sostenibilidad Social. Colección Estudios Sociales, No. 27, Fundación La Caixa, Barcelona.

[32] Reher, D.S. and Silvestre, J. (2009) Internal Migration Patterns of Foreign-Born Immigrants in a Country of Recent Mass Immigration: Evidence from New Micro Data for Spain. International Migration Review, 43, 815-849. http://dx.doi.org/10.1111/j.1747-7379.2009.00785.x

[33] Méndez, R., Abad, L.D. and Echaves, C. (2015) Atlas de la crisis, Impactos Socioeconómicos y Territorios Vulnerables en España, Ed. Tirant lo Blanch.

[34] European Commission (2008) The EU Rural Development Policy: Facing the Challenges. Rural Development Policy 2007-2013. http://ec.europa.eu/agriculture/ events/cyprus2008/brochure_en.pdf

[35] OECD (2004) Trends in International Migration 2004.

http://www.oecd.org/migration/mig/trendsininternationalmigration2004.htm 